\title{
Agenda Setting Theory and International News: A Comparative Analysis of News Articles Coverage on Iraq War in Malaysian English Newspapers
}

\author{
Hanaa Kadum Kassed ${ }^{2}$, and Che Su Mustaffa, ${ }^{1, *}$ \\ ${ }^{1}$ School of Multimedia Technology and Communication, College of Art and Science, Universiti Utara \\ Malaysia. \\ ${ }^{2}$ Ministry of Science and Technology, Baghdad, Iraq
}

\begin{abstract}
The main purpose of the paper is to discuss the application of Agenda Setting Theory in the publication of news about Iraq war in - the New Straits Times press (NSTP) and the Star. This study examines a longitudinal content analysis of 535 news through three periods (before, during and after the occupation of Iraq). The result of this study shows that NSTP gave more emphasis to the issue of the policy of unipolar for the United States while the Star gave more emphasis to the issue of Iraqi suffering. Thus, this study can shed some light on how Eastern country views Iraq and this perhaps could help Iraq reform its image by expanding the scope of diplomatic, business and cultural actions. This study provides support to the theoretical proposition that the media are not successful in telling the audience what to think, but it is stunningly successful in telling the audience what to think about (first level of Agenda Setting). This study also provides support to the theoretical proposition that differences in media organizations have profound impact on how the important issues are framed.
\end{abstract}

\section{Introduction}

The mass media played a crucial role in constructing the images of various societies and their people [1]. Mass media news on certain country itself can affect their image on society. The image that will appear could be positive, negative or neutral depending on the content in it. McCombs and Shaw [2] claimed that the mass media pays attention to certain issues. It builds up public images of political figures and it constantly presents objects suggesting what individuals should think about, know about and how they should feel. Perhaps, this hypothesized Agenda Setting Function of the mass media is most succinctly

*Corresponding author: chesu402@uum.edu.my 
stated by Cohen [3], that a successful press tells the readers what to think, so the media sets the Agenda Setting for issues.

\section{Problem statement}

The media greatly affects the image in the minds of people from the outside world. The Agenda Setting Theory effects also have significant implications beyond the images that have been created in people's heads. Originally, the Agenda Setting Theory focused on the salience of issues [2]. Thus, this paper discusses the differences in the portrayal of Iraq in Malaysia by studying two English newspapers, NSTP and the Star, which belong to two different political parties. The United Malays National Organization (UMNO) consists of a majority of Malays, while the Malaysian Chinese Association (MCA) consists of a majority of Chinese. UMNO dominates the political system [4], while MCA is the second largest political party in Malaysia [5]. UMNO owns $80 \%$ of NSTP shares while the MCA owns $58 \%$ of the Star's shares [6]. In addition, the New Straits Times Press and the Star have the highest circulations in the country.

On the whole, in Malaysia the media reflect the policy of the government and the society in which they operate [7]. Firdaus [8] explained that the Malay political party, $\mathrm{UMNO}$, and the Chinese political party, MCA, are components of the ruling coalition, Barisan Nasional. However it cannot be denied that each party cares for its ethnic interests. A cursory look at the different newspapers should indicate different agenda. These agenda are then relayed back to their readers, "for example, the Malay Mail and the New Straits Times are both owned by the News Straits Times Press but cover different types of stories with the Malay Mail running more human interests and sensationalistic stories. Utusan Malaysia is closely linked to the Malay political party (UMNO), while the Star is closely affiliated to the Chinese political party (MCA)" [8]. Khiang, Ahmad and Kee [9] see the differences of interest and the upholding the rights of the community served by the ethnic newspapers can be seen from its focus and suggest that future researches should consider English newspapers. In conclusion, the ownership of newspapers probably influenced to a greater degree the Agenda Setting Theory.

\section{Method}

The theory of agenda setting has served as one of the most powerful and fertile concepts in mass media and communication effects research [10]. Agenda-setting theory entails the link between the mass media's emphasis on a particular topic and the corresponding salience of that topic on the public agenda [11]. A more recent definition by Brosius and Kepplinger [12] defines agenda setting as a dynamic process 'in which changes in media coverage lead to or cause subsequent changes in problem awareness of issues'. In other words, when mass media prioritise and frequently cover a topic, the public tends to consider this topic more important.

The origins of agenda-setting theory can be traced back to Walter Lippmann and his 1922 book Public Opinion. Lippmann [13] was the first to ascertain the mass media's critical role in creating and shaping the images and perceptions about the world in the minds of the public, who have little unmediated experience of distant real-world events. Related to Lippmann, another influential idea comes from Cohen [3], who suggests that 'the press may not be successful much of the time in telling people what to think, but it is stunningly successful in telling its readers what to think about'. Hence, rather than injecting ideas and ways of thinking into the public's mind like a hypodermic needle, agenda-setting 
theory contends that the public learns about the importance of topics in direct proportion to the amount of media coverage of those topics [2]. Since the formal introduction of agendasetting theory by McCombs and Shaw [11] in the Chapel Hill study on the 1968 US presidential election, a myriad of studies around the world have found correlations between media agendas and public agendas (e.g. $[14,15])$. On a socio-political level, these USinfluenced studies largely ignored non-Western countries with, for example, communist political systems.

This study employed a quantitative content analysis as quantitative content analysis is proven to be a more powerful method than survey and interview because of its unobtrusive nature and its lack of reliance on subjective perception. This study analyses the publication of news stories and articles in the NSTP and the Star newspaper during a specific period. The sample was collected from the published news stories and articles during the three periods (before the occupation 15 January 2002 until 8 April 2003, during the occupation 9 April 2003 until 28 June 2004 and after the occupation 29 June 2004 until 18 September 2005) of both newspapers. The sample for this study was identified through a guided search using library database from Universiti Utara Malaysia (UUM) called Blis BERNAMA.

This study investigates four issues, namely, The US policy and the occupation of Iraq, Iraq's needs and suffering, The Malaysia's policy towards Iraq, and The impact of war on Malaysia. These issues were selected because these were the most covered issues during the periods studied. The four categories are as follows:

- The US policy and the occupation of Iraq: This category refers to invasion of Iraq without a UN mandate and under the excuse of weapons of mass destruction which later led to resist occupation. It also refers to US double-standard policy which was evidenced by its support for Israel's occupation of Palestine, and to the invasion of Iraq as an occupation, not liberation. Furthermore, this category also includes the opposition from the countries toward the US policy, and their concern that the real reason for the invasion was oil and not weapons of mass destruction. Finally, this category also refers to the emergence of the looters under the state of lawlessness in the country.

- Iraq's needs and suffering: This refers to the suffering the Iraqi people faced before, during and after the US occupation. As a result of the military disaster which have taken the lives of a number of innocent civilians (women and children), Iraqis needed food, shelter, medicine, sanitation, electricity, safety and security in addition to the need for medical and humanitarian assistance Moreover, they suffered through what they had seen from the horrors of Abu Ghraib prison and also from the keenness of the occupation forces not to revealed the correct number of victims. Also, there was a need to form an Iraqi government as well as the need to rebuild the country.

- The Malaysia's policy towards Iraq: refers to Malaysia rejecting the US policy towards the Middle East, and to show support for Iraq and Palestine, Malaysia is against the war and occupation of Iraq. This has led to a tensed relationship between Malaysia and the US.

- The impact of war on Malaysia: refers to the impact of the Iraq war on the Malaysian economy and Malaysians living in Iraq and the neighboring countries of Iraq (refers to the Malaysian embassy staff and their families in addition to Malaysian students). For example, the mission to evacuate Malaysians from Iraq and the neighboring countries of Iraq and drop in tourist arrivals from West Asia. 


\section{Findings and discussion}

The analysis focused on a comparison of issues relating to Agenda Setting issues in NSTP and the Star descriptively. Figure 1 show an analysis conducted between the two newspapers on Agenda Setting issues for the period before the occupation. In general, the analysis shows, the Agenda Setting issues are displayed in the NSTP more than the Star. The issues related to "The Malaysia's policy towards Iraq" published by NSTP were 44 (53.0\%) news, as compared to the Star 39 (47.0\%). For instance, Malaysia as the chair of the 116-nation Non- Aligned Movement will continue to speak up against the invasion of Iraq. Foreign Minister Datuk Seri Syed Hamid Albar said it was the nation's responsibility to push for NAM's stance to be heard by the world, NAM has no military might to do anything to stop the war, but it's better than of silence. Although there are various forms of pressures against our stance, but if we are united, we can influence the decisions on the situation in Iraq and also the future of world order (New Straits Times, 28 March, 2003).

Similarly, the issue relating to "The US policy and the occupation of Iraq" covered 63 news $(71.6 \%)$ in the NSTP compared to $25(28.4 \%)$ in the Star. It shows that NSTP (on 18 July 2002; 24 November 2002 and 13 September 2002) focused about the US desire to control the world as the dominant power, through resolutions of military action against Iraq.

Also, the issue related to "The impact of war on Malaysia" was featured in NSTP in $37(67.3 \%)$ articles and news stories, more than the Star which only published 18(32\%) articles and news stories for the periods concerned. For example, according to a report in NSTP on 11 February 2003, Malaysia's timber and palm oil exports will be affected if a war breaks out in Iraq, due to the disruption in shipments as well as rising freight and insurance charges.

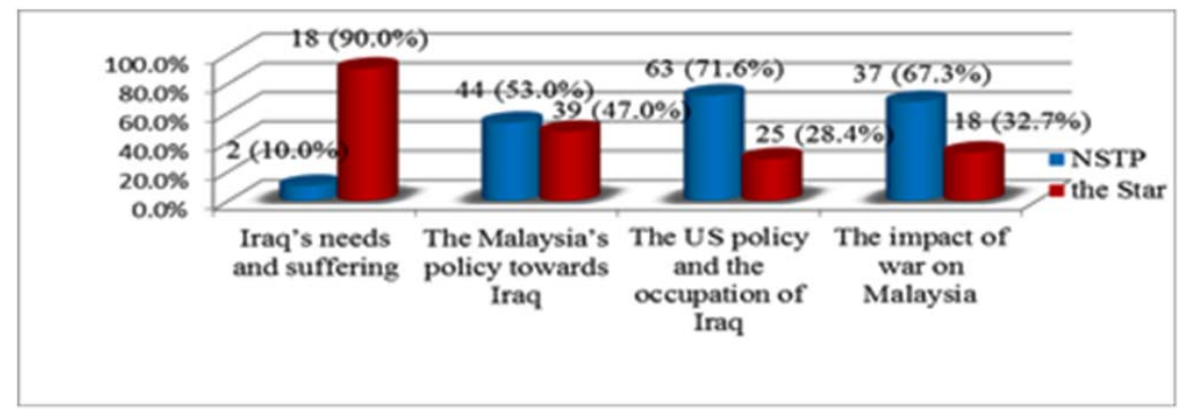

Fig. 1. Comparison of Agenda Setting Issues before the Occupation between NSTP and The Star

The next research question is related to the display of news related to the Agenda Setting issue during the occupation. Figure 2 shows that there is little difference in the Agenda Setting issues published by both newspapers. The Star was found to be more focused on articles and news stories about two issues which are "Iraq's need and Suffering" and "The impact of war on Malaysia" with $30(61.2 \%)$ and $25(59.5 \%)$ news stories published respectively. Meanwhile, NSTP published 19 (38.8\%) and $17(40.5 \%)$ articles and news stories respectively. This issue which covers "Iraq's need and Suffering" includes the discussion on how current situation in Iraq was worsening because of many factors, like their existence a political vacuum in Iraq, and many Iraqis feel that the existing political process lacks legitimacy. Thus the Iraqi people need to end the occupation and transfer the power back to Iraqis (New Straits Times, 19 April, 2004). Meanwhile, the issue which 
covers "The impact of war on Malaysia" includes the discussion on how the Iraq war which led to the decline in gross domestic product (GDP) due to the lower export growth coupled with declining tourism and weaker private consumption, would contribute to a bleaker economic picture for the country (New Straits Times, 2 April, 2003).

The NSTP published more articles and news stories related to issues of "The Malaysia's policy towards Iraq" with 31(66.0\%) news compared to the Star which only published 16 news (34.0\%). For example, on 13-21 April 2003, NSTP published news about Malaysia call for an end of the US occupation in Iraq, especially after unseating of Saddam's administration, on the basis that the coalition was not occupation force and that it only wanted to topple Saddam Hussein's administration. The news also reported a peaceful march by Malaysians to protest against the United States-led invasion of Iraq, where many of them held anti-war placards.

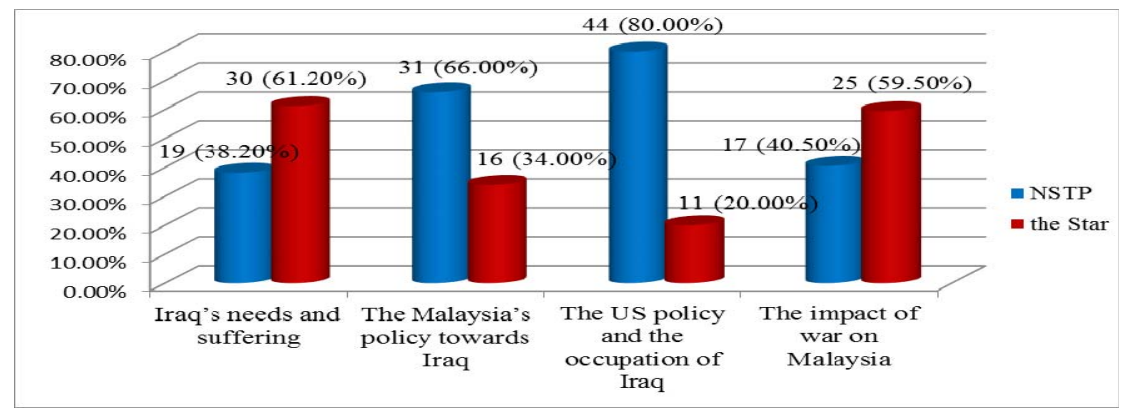

Fig. 2. Comparison of Agenda Setting Issues during the occupation between NSTP and the Star

Looking at the prominent issues constructed by NSTP and the Star for the period after the occupation (Figure 3), the analysis shows NSTP published more news related to the issue of "Iraq's need and Suffering" with 18 (54.5\%) news compared to the Star which published $15(45.5 \%)$, where the news were devoted to the percentage of Iraqis who have successfully undergone their first free election with a very encouraging turnout of voters. It was reported that Iraqis wanted to determine their own future with the new government without any direct intervention from the US (New Straits Times, 3 February, 2005). Another news was about the abuse of Iraqi detainees at Abu Ghraib prison in Iraq, suggesting that that the Iraqi people need respect for human rights (New Straits Times, 5 August, 2004).

The issue of "The Malaysia's policy toward Iraq" was published more in NSTP with $21(84.0 \%)$ articles and news stories compared to the Star with only $4(16.0 \%)$ articles. Malaysia's policy was reflected in news that reported Malaysia will decide on sending troops for peacekeeping to Iraq only under three conditions which are: first, Ordinary Iraqis want troops from an organization of the Islamic Conference (OIC) member country; second, the troops are not deployed alongside the multinational forces led by the United States; third, a joint decision is reached by the OIC on sending troops to Iraq (New Straits Times, 6 August, 2004). 


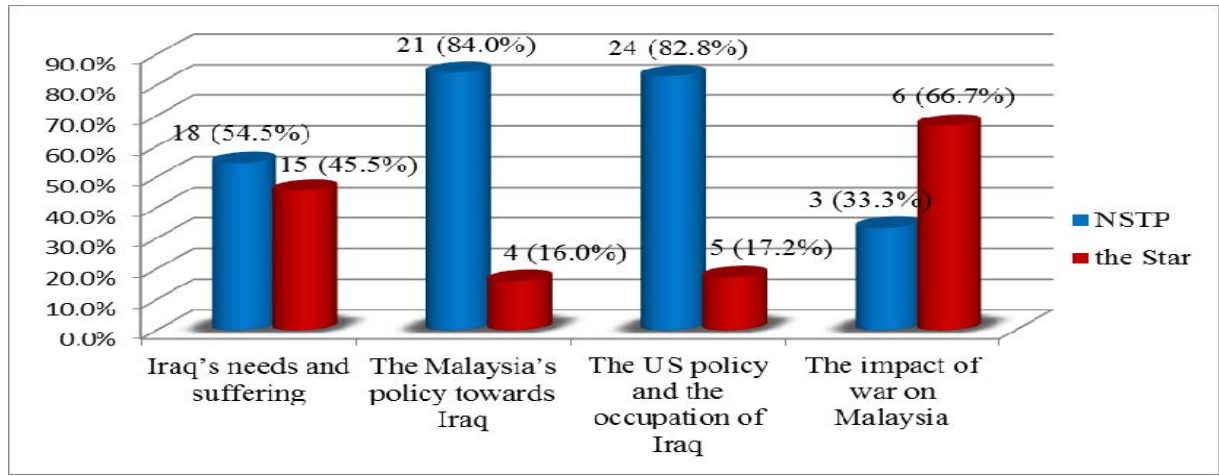

Fig. 3. Comparison of Agenda Setting Issues after the occupation between NSTP and The Star

\section{Conclusion}

The results of this study contribute toward the understanding of the Agenda Setting process in mass communication. Agenda Setting is a function that the media can play. By deciding what is important, media set the agenda for content within their own pages. For example, it can change a position on an issue such as war. The result of the study proved that the NSTP and the Star focused on different Agenda Setting issues about Iraq through the three periods. NSTP published more articles and news stories about "The Malaysia's policy towards Iraq" and "The US policy and the occupation of Iraq" than the Star. These findings are consistent with the foreign policy which turned Malaysia from having a pro-Western stance in the fifties and sixties to the policy of Non-Aligned Movement in the seventies and after the advent of Tun Dr. Mahathir Mohamad in 1981. In addition, Malaysia continued to support the Iraqi people in the face of UN sanctions and US military strikes. The former Prime Minister of Malaysia, Tun Dr. Mahathir condemned the plans of the United States and Britain to launch an attack against Iraq without a good reason. This finding also support the argument that Malaysia newspapers, in particular the English language newspapers have provide better and healthier reporting's in line with the Malaysia Political Transformation Plan agenda [16].

The findings also indicated that Agenda Setting is the phenomenon of the mass media selecting certain issues and portraying them frequently and prominently, which leads people to perceive those issues as more important than others. The first level Agenda Setting focuses on the amount of coverage of an issue, suggesting that the media decide what issues the public will be aware of. Current study provides evidence that "what to think about" is the first level of the Agenda Setting Theory.

Finally, these findings support Agenda Setting Theory that the amount of coverage devoted to an issue by the media agenda translates into salience about that issue on the public agenda. Further, a contribution is made to the discussion concerning the time frame it takes for an issue to emerge, be covered by the mass media, and translate into public salience. It can be concluded that NSTP reflects the expressive policy of UMNO which was known to be very critical of the US approach, while the Star focused more on sensationalized issues because it is one of the most profitable companies listed on the Kuala Lumpur Stock Exchange. 


\section{References}

1. N. Saleem, U.S. Media Framing of Foreign Countries Image: An Analytical Perspective. Canadian Journal of Media Studies, 2, 1 (2002).

2. M. McCombs, M. Setting the Agenda: The Mass Media and Public Opinion. Cambridge, UK: Polity Press. (2004).

3. B. Cohen. The press and foreign policy. New York: Harcourt. (1963).

4. A. Humphreys. Malaysia's post 9/11 security Strategy: winning "hearts and minds" or legitimising the political status quo? Kajian Malaysia, 28, 1 (2010).

5. M. K. Lim, The State of Media Control in Malaysia. Paper presented at the annual meeting of the International Communication Association 23 May 2007. US: San Francisco (2007).

6. Z. Nain, \& Kim, W. I. Ownership, control and the Malaysian media. Who Owns the Media. Penang: Southbound, 249-270 (2004).

7. F. Ibrahim., Mustaffa, N., Kee, C. P., \& Ahmad, F. Innov J. 16, 3 (2011).

8. A. Firdaus. Ethnic Identity and News Media Preferences in Malaysia. Paper presented at ARC APFRN Signature Event. Australia, Perth: Curtin University. 27-29 (2006).

9. C. C. Khiang, Ahmad, F., \& Kee, C. P. The Framing of media on contemporary education issue in Malaysia. Paper presented at the International conference on media and communication 11 - 12 October. 2011. Kuala lumpur: Malaysia. (2011).

10. J., Bryant, J., \& Miron, D. J. Commun., 54, 4 (2004)

11. McCombs, M., \& Shaw, D. L. The evolution of agenda setting research: Twenty-five years in the marketplace of ideas. J. Commun., 43, 2 (1972).

12. H. B. Brosius, \& Kepplinger, H. M. The Agenda-Setting Function of Television News: Static and Dynamic Views. Communication Research, 17, 2 (1990).

13. W. Lippmann. Public opinion. New York: Harcourt. (1922).

14. J. W. Dearing, \& Rogers, E. Agenda-setting. London: SAGE. (1996).

15. D. Weaver, Graber, D., McCombs, M., \& Eyal, C. Media agenda setting in a presidential election: Issues, images and interest. Westport, CT: Greenwood Publishing Group. (1981).

16. A. Mohd Khairie \& Mohd Baharudin O. General Election and the Enigma of Free Press in Malaysia. Procedia - Social and Behavioral Sciences, 155 (2014). 